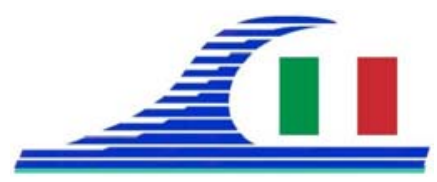

Conférence Méditerranéenne Côtière et Maritime EDITION 3, FERRARA, ITALIA (2015)

Coastal and Maritime Mediterranean Conference

Disponible en ligne - http://www.paralia.fr - Available online

\title{
Feasibility long-term numerical study of a mega-nourishment in the Northern Adriatic
}

\author{
Enrico DUO ${ }^{1}$, Alessandra CASARI ${ }^{1}$, Paolo CIAVOLA ${ }^{1}$ \\ 1. Department of Physics and Earth Science, University of Ferrara, Via Giuseppe \\ Saragat 1, 44122, Ferrara, Italy. \\ duonrc@unife.it.
}

\begin{abstract}
The coastal area of Porto Garibaldi - Bellocchio (Ferrara, Italy) is subjected to erosion that affects both tourism and generates coastal risk. Mega-nourishments are nowadays one of the most promising measures to compensate erosion and the Dutch Sand Engine project is confirming their capability. A first-step numerical study of the implementation of a small mega-nourishment in the target area is described here including long-term impact-factor analyses on erosion, deposition and sediment transport. Results suggested that the measure can have long-term positive impacts on morphology and transport. Further studies are suggested to overcome the limitations and simplifications introduced in the current study.
\end{abstract}

Keywords: Mega-nourishment, Erosion, Long-term measure, Coastal modelling.

\section{Introduction}

The target coastal area of this study stretches from Porto Garibaldi (Ferrara, Italy) to the Reno river mouth in the Emilia-Romagna coast: it consists of an highly touristic urbanized area in the north and a natural area (Bellocchio) in the south. Both are affected by erosion that increases the risk of inundation and negatively affects the tourism (NORDSTROM et al., 2015). Moreover, the Reno river mouth in the south does not provide consistent sediment supply (PRECISO et al., 2012). The area was selected as demonstrative case study of the RISC-KIT EU FP7 Project (VAN DONGEREN et al., 2015).

Mega-nourishments are nowadays one of the most promising measures to compensate erosion (DE VRIEND \& VAN KONINGSVELD, 2012; STIVE et al., 1991). The best example is the Dutch Sand Engine, a $20 \times 10^{6} \mathrm{~m}^{3}$ localized nourishment that is still under investigation by numerical modelling and direct observations. The results of the studies, even if based on a short period of time, already showed its positive effects (STIVE et al., 2013 \& 2015).

The aim of this study was to create a starting point for the implementation of a small mega-nourishment of $10^{6} \mathrm{~m}^{3}$ volume, built in a simple and symmetric shape (bell-shape, $500 \mathrm{~m}$ wide and $500 \mathrm{~m}$ long), in the target area. As a first approach, a simplified longterm numerical investigation was implemented focusing on the impact of the measure on erosion/deposition and sediment transport. 
Côtes méditerranéennes menacées :

Risques et défis dans le contexte du changement climatique

\section{Materials and Methods}

\subsection{Modeling approach, data sources and model setup}

The study was performed through a Delft3D hydro-morphodynamic simplified model. As the main aim of the study was to describe the long-term impact of a Sand Engine on the target area, the choice was to set up a model of the Current State (CS) to compare with a Design State (DS) which included the presence of a Sand Engine (SE) of about $10^{6} \mathrm{~m}^{3}$. It follows that several main simplifications and default settings were applied such as: (i) computation of a simplified semidiurnal harmonic tide given through water level boundary conditions; (ii) forcing waves as average wave climates; (iii) rivers discharge not included ; (iv) simplified and default assumptions on sandy sediments characteristics; (v) simplified and default morph-dynamics processes. As no consistent observation were available, no calibration procedure was applied. Thus, the numerical results can only be analyzed as a comparison between a current situation and the variations induced by an hypothetical design state.

The original bathymetry and topography of the area were collected in 2012 by ARPA Emilia-Romagna. The wave data were measured by the Cesenatico buoy of ARPASIMC and re-elaborated into an average wave climate used in this study. The sediment and morphology characteristics were supported by field measurements implemented in fall 2014 which results are not reported here.

In order to simulate the long-term morph-dynamics of the CS and DS, four Modeling Waves (MW) were used (Hs=0.4 $\div 1 \mathrm{~m}, \mathrm{Tp}=4 \div 5.2 \mathrm{~s}$ and Dir=50 $\div 100$ naut. degs). In order to simulate the morphological changes into 1 and 10 years, different morphological time scale factors (MorFac) were applied. Four monitoring crosssections (MCS) were introduced in the model (Figure 1). A combination of the $4 \mathrm{MW}$ and the 2 MorFac, for both CS and DS, were implemented for a total of 16 runs.

\subsection{Analyses approach}

In order to characterize the geometrical influence of the mega-nourishment, a Geometric Index (GI) was calculated, for each cross-shore profile of the grid, as the difference between the integration on the whole cross-shore distance of the initial depths for the design (giving $\mathrm{A}_{\mathrm{in}}{ }^{\mathrm{DS}}$ ) and current (giving $\mathrm{A}_{\mathrm{in}}{ }^{\mathrm{CS}}$ ) states. Then, the difference in terms of areas $\left(A_{\text {in }}\right.$ and $\left.A_{\text {out }}\right)$ between the initial and the final profiles was calculated for both current and design states $\left(\mathrm{dA}^{\mathrm{CS}}\right.$ and $\left.\mathrm{dA}^{\mathrm{DS}}\right)$.

In order to quantitatively define the impact of the Sand Engine an Erosion/Deposition Impact Factor (EDIF) was calculated as the difference between $\mathrm{dA}^{\mathrm{CS}}$ and $\mathrm{dA}^{\mathrm{DS}}$ for each profile of the model, for each average wave climate. In order to assess the cumulative impact of the wave climates, the same procedure was applied linearly summing their effects, giving global $\mathrm{dA}^{\mathrm{CS}}, \mathrm{dA}^{\mathrm{DS}}$ and EDIF. 
To quantitatively assess the impact on sediment transport, the Sediment Transport Impact Factor (STIF) was calculated for each MCSs, as the ratio between $\mathrm{Q}_{t}{ }^{\mathrm{CS}}$ and $\mathrm{Q}_{\mathrm{t}}{ }^{\mathrm{DS}}$, that are the volumes of the cumulative total sediment transport for the current and design states, respectively. In particular: (a) $|\mathrm{STIF}|<1$ means negative impact: the total sediment transport decreases in volume; (b) $|\mathrm{STIF}|>1$ means positive impact: the total sediment transport increases in volume. A negative STIF value means that the transport in the design state was in the opposite direction of the transport of the current state. A slightly finer classification was used in the results analyses, considering that $0.95<\mid$ STIF $\mid<1.05$ means no consistent impact. The STIF was calculated for each of the MCSs in the model, for each MW. Moreover, in order to get an idea of the cumulative impact of the wave climates, a linear sum of the effects was implemented to calculate a global STIF for each MCS over 1 year, summing $\mathrm{Q}_{\mathrm{t}}{ }^{\mathrm{CS}}$ and $\mathrm{Q}_{\mathrm{t}}^{\mathrm{DS}}$ from each simulation.

\section{Results}

The EDIF cumulative impact is shown in Figure 1. Whereas here are only described the cumulative results, it is important to report that the EDIF was sensitive to the wave direction and intensity, predominant factors compared to the frequency of the wave climates. The Sand Engine was consistently eroded on the tip with sediments moved to its sides. Notably, the Sand Engine behaved similarly to a groin but it did not affect the whole domain except for a stretch of $1 \mathrm{~km}$ in both sides of the SE. In Table 1 the STIF results are shown for each MW and their cumulative impact. The impacts were consistent mainly for the MCSs nearby the Sand Engine. Positive impacts are given for three MW. Waves approaching the coast from the south produced the best positive impacts. In global terms, the positive impacts on the sediment transport were found in the south of the Sand Engine.

\section{Conclusions}

A simplified Delft3D model was setup to assess the impact of the implementation of a Sand Engine (SE) on the Northern Adriatic Italian coast of Emilia-Romagna comparing the current situation with an hypothetical design situation. The EDIF was used to analyze the impact on erosion and deposition while the STIF to analyze the sediment transport variations. Focusing on erosion and deposition: (i) the Sand Engine affected a coastline of $2 \mathrm{~km}$ and no consistent impact can be noted on the borders of the domain; (ii) the tip of the Sand EngineE was consistently eroded with sediments mainly moved on its sides (depending on the wave climate); (iii) a morpho-hydrodynamics similarity between the Sand Engine and a groin can be noted. The sediment transport analyses evidenced: (i) the border cross-sections are not consistently affected; (ii) consistent positive impacts were given for wave climates from the south; (iii) the global analysis showed an increase in the transport on the south of the Sand Engine. 
Côtes méditerranéennes menacées :

Risques et défis dans le contexte du changement climatique

Future developments will be based on eliminating the simplifications introduced: (i) the long term approach did not include the effect of extreme events; (ii) the lack of observations made the model a semi-realistic one; (iii) the forcing wave climates were applied independently and not consequently. Firstly, an investigation of the impact of extreme events has to be applied in order to assess the response of the SE to low frequency - high intensity events. Then, a comparison with field observations must be done to make the model more realistic. The model itself needs improvements in terms of resolution. Finally, some effort will be put in order to build more reliable and detailed average wave climates that can be run consequently and not separately as in this study.
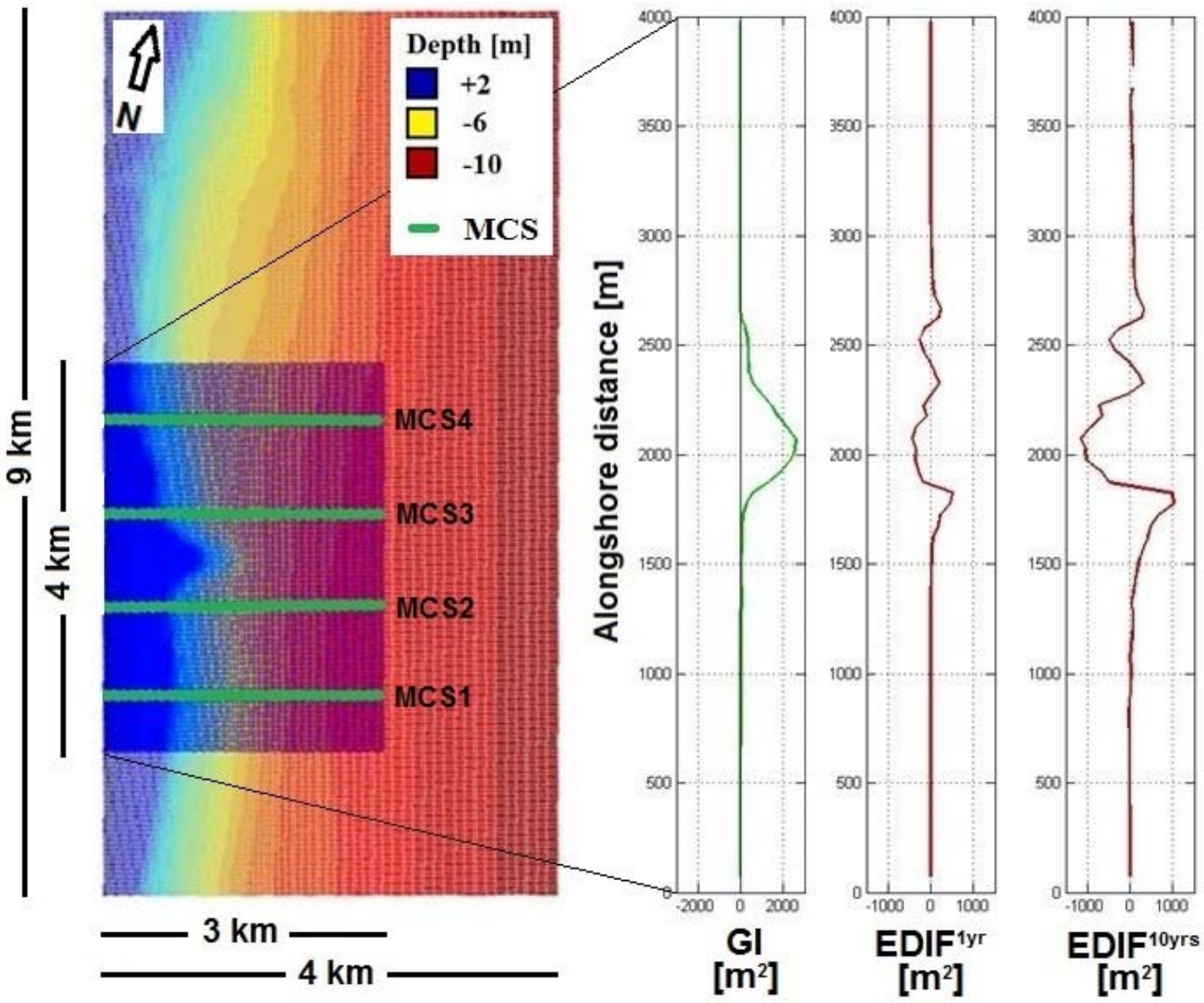

Figure 1. Left: FLOW-WAVE Model size, depth and MCSs; Right: Global cumulative impact on erosion and deposition: GI (green line) and EDIF (red lines) for1 and 10 years projections. 
Mediterranean coasts at threat:

Hazards and challenges in the context of climate variability

Table 1. Overview of the STIF for each MW and their global impact on the 4 MCS over 1 year (positive impact: green; negative impact: red; no consistent impact: orange).

\begin{tabular}{cccccc} 
Cross-section & $\boldsymbol{M} W \mathbf{1}$ & $\boldsymbol{M W} \mathbf{2}$ & $\boldsymbol{M W}$ & $\boldsymbol{M W 4}$ & Global \\
\hline MCS1 & 0,99 & 1,02 & 0,99 & 1,04 & 1,02 \\
\hline MCS2 & 0,34 & 1,08 & 0,67 & $-1,68$ & 1,51 \\
\hline MCS3 & 0,24 & $-0,01$ & $-2,12$ & 15,43 & $-0,70$ \\
\hline MCS4 & 1,00 & 0,93 & 0,99 & 1,03 & 1,03 \\
\hline
\end{tabular}

\section{References}

DE VRIEND H.J., VAN KONINGSVELD M. (2012). Building with Nature: Thinking, acting and interacting differently. EcoShape, Building with nature, Dordrecht, the Netherlands. URL :www.ecoshape.nl/files/paginas/ECOSHAPE_BwN_WEB.pdf

NORDSTROM K.F., ARMAROLI C., JACKSON N.L., CIAVOLA P. (2015). Opportunities and constraints for managed retreat on exposed sandy shores: Examples from Emilia-Romagna, Italy. Ocean \& Coastal Management, Vol. 104, pp 11-21. http://dx.doi.org/10.1016/j.ocecoaman.2014.11.010

PRECISO E., SALEMI E., BILLI P. (2012). Land use changes, torrent control works and sediment mining: effects on channel morphology and sediment flux, case study of the Reno River (Northern Italy). Hydrological Processes, Vol. 26, pp 1134-1148. http://dx.doi.org/10.1002/hyp.8202

STIVE M.J.F.; NICHOLLS R.J., DE VRIEND H.J. (1991). Sea-level rise and shore nourishment: a discussion. Coastal Engineering, Vol. 16(1), pp 147-163. http://dx.doi.org/10.1016/0378-3839(91)90057-N

STIVE M.J.F., DE SCHIPPER M.A., LUIJENDIJK A.P., AARNINKHOF S.G.J., VAN GELDER-MAAS C., VAN THIEL DE VRIES J.S.M, DE VRIES S., HENRIQUEZ M., MARX S., RANASINGHE R. (2013). A New Alternative to Saving Our Beaches from Sea-Level Rise: The Sand Engine. Journal of Coastal Research: Vol. 29(5), pp 1001-1008. http://dx.doi.org/10.2112/JCOASTRES-D-13-00070.1

STIVE M.J.F., DE SCHIPPER M.A., DE VRIES S., AARNINKHOF S.G.J., VAN KONINGSVELD M., GELDER-MAAS C., RUESSINK B.G., VAN THIEL DE VRIES J.S.M. (2015). Morphological development of the sand engine after 18 months of existence. E-proceedings of the 36th IAHR World Congress 28 June - 3 July, 2015, The Hague, the Netherlands. URL : http://89.31.100.18/ iahrpapers/89877.pdf

VAN DONGEREN A., CIAVOLA P., VIAVATTENE C., DE KLEERMAEKER S., MARTINEZ G., FERREIRA O., COSTA C., MCCALL R.(2014).RISC-KIT: Resilience-Increasing Strategies for Coasts - toolkit. In: Green, A.N. and Cooper, J.A.G. (eds.), Proceedings 13th International Coastal Symposium (Durban, South Africa), Journal of Coastal Research, Special Issue No. 70, pp 366-371. http://dx.doi.org/10.2112/SI70-062.1 
Côtes méditerranéennes menacées :

Risques et défis dans le contexte du changement climatique 